\title{
Prayer in the Sayings Gospel Q
}

\author{
Edited by \\ Daniel A. Smith and Christoph Heil
}

Mohr Siebeck 
Daniel A. Smith, born 1963; 2001 Ph.D. from the University of St. Michael's College, University of Toronto; 2004 Assistant Professor of New Testament Language and Literature, Huron University College; since 2018 Clark and Mary Wright Professor of New Testament Theology, Faculty of Theology, Huron University College, London, Canada.

Christoph Heil, born 1965; 1994 Dr. theol. from the University of Bonn; 2000 Habilitation from the University of Bamberg; since 2004 Professor for New Testament; since 2017 Dean of the Catholic Theological Faculty of the Karl-Franzens-University Graz.

orcid.org/0000-0002-3434-0674

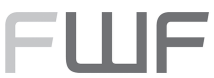

Der Wissenschaftsfonds.

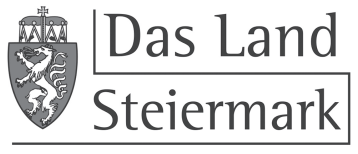

Wissenschaft und Forschung
The authors acknowledge the financial support of the University of Graz.
Published with the support of the Austrian Science Fund (FWF): P 26844-G19, and Land Steiermark: Abteilung Wissenschaft und Forschung.

ISBN 978-3-16-156660-8 / eISBN 978-3-16-156661-5

DOI 10.1628/978-3-16-156661-5

ISSN 0512-1604 / eISSN 2568-7476

(Wissenschaftliche Untersuchungen zum Neuen Testament)

The Deutsche Nationalbibliothek lists this publication in the Deutsche Nationalbibliographie; detailed bibliographic data are available at $h t t p: / / d n b . d n b . d e$.

(C) 2019 Mohr Siebeck Tübingen, Germany. www.mohrsiebeck.com

This book may not be reproduced, in whole or in part, in any form (beyond that permitted by copyright law) without the publisher's written permission. This applies particularly to reproductions, translations and storage and processing in electronic systems.

The book was typeset by epline in Böblingen using Minion typeface, printed on non-aging paper by Gulde Druck in Tübingen, and bound by Großbuchbinderei Spinner in Ottersweier.

Printed in Germany. 


\section{Table of Contents}

Daniel A. Smith and Christoph Heil

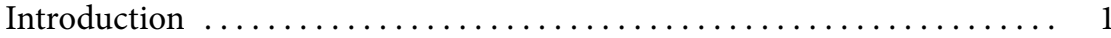

Irmtraud Fischer

Mehr reden über das Gebet als Beten:

Eine Alttestamentlerin liest Gebetstexte in Q $\ldots \ldots \ldots \ldots \ldots \ldots \ldots \ldots .11$

Ursula Schattner-Rieser

The Lord's Prayer in the Context of Jewish-Aramaic Prayer Traditions

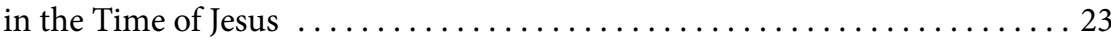

Simon J. Joseph

The Promise of Providence and the Problem of the Parables:

Revisiting Prayer in the Sayings Gospel Q .................. 57

Karl-Heinrich Ostmeyer

Beten für und gegen Feinde $\ldots \ldots \ldots \ldots \ldots \ldots \ldots \ldots \ldots \ldots \ldots$

Catherine Hezser

Prayer in the Sayings Source Q and in Early Rabbinic Texts ........... 103

Hildegard Scherer

Gott und die Feinde: Traditionen und neutestamentliche Vernetzung

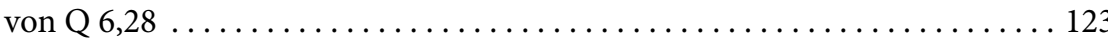

Markus Tiwald

Gebet und Gottesreich: Gebetstexte aus Q im Vergleich mit den

qumranischen Sabbatopferliedern $\ldots \ldots \ldots \ldots \ldots \ldots \ldots \ldots \ldots \ldots \ldots \ldots \ldots$

Michael Labahn

Identitätsstiftung durch Jesu Gebet: Q 10,21-24, Jesus

und die Offenbarung an die Unmündigen

Giovanni B. Bazzana

Praying to God and the Kingdom: Q's Lord's Prayer in Its Rhetorical

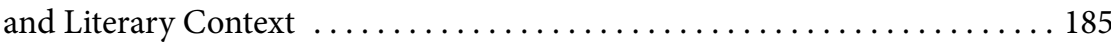


John S. Kloppenborg

The Lord's Prayer and Debt Recovery:

Insights from Graeco-Egyptian Papyri

Thomas Klampfl

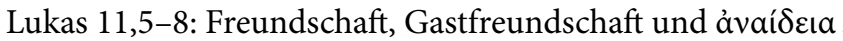

\section{Niclas Förster}

Die lukanische Rezeption der Gebetstexte in Q im Kontext des

frühen Judentums und Christentums

Daniel A. Smith

The Influence of Q's Prayer Texts in Matthew 261

List of Contributors

Index of Ancient Sources . . . . . . . . . . . . . . . . . . . 285

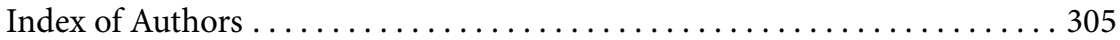

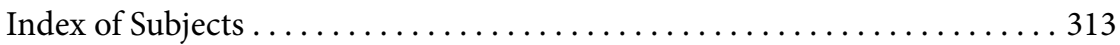




\title{
Prayer in the Sayings Source Q and in Early Rabbinic Texts
}

\author{
Catherine Hezser
}

The Sayings Source Q in its critical reconstruction from the gospels of Matthew and Luke is believed to represent (one of) the earliest collection(s) of traditional material associated with Jesus, going back to the very end of the Second Temple period and the First Jewish Revolt against Rome. ${ }^{1}$ It is considered to have been created by Jewish Christians at a time when another Jewish Christian group was stationed in Jerusalem and Paul and Stephanus had begun their mission among gentiles. ${ }^{2}$ Prayer appears in the collection only incidentally: Jesus is only once presented as praying ( $\mathrm{Q}$ 10:21). More often, he gives instructions concerning prayer $(\mathrm{Q} 4: 8 ; 6: 28 ; 10: 2 ; 11: 2 \mathrm{~b}-4 ; 11: 9-13)$. The references to prayer are interwoven in story traditions (Q 4:4-8: Jesus' encounter with the devil) and appear

${ }^{1}$ A critical reconstruction of the text began with the International Q Project (IQP) of the Society for Biblical Literature (SBL) in the 1990 os and was continued by colleagues in Bamberg, Claremont, and Toronto. The results are published in James M. Robinson, Paul Hoffmann, and John S. Kloppenborg, eds., The Critical Edition of Q, Hermeneia Supplements (Minneapolis: Fortress; Leuven: Peeters, 200o). Reconstructions and translations of Q in this essay are taken from the Critical Edition of Q. See also James M. Robinson, Paul Hoffmann, and John S. Kloppenborg, eds., The Sayings Gospel Q in Greek and English (Leuven: Peeters, 2001; Minneapolis: Fortress, 2002); James M. Robinson, ed., The Sayings of Jesus: The Sayings Gospel Q (Minneapolis: Fortress, 2002). For questions concerning its possible date and relationship to Mark, Matthew, and Luke, see John S. Kloppenborg, Q, The Earliest Gospel: An Introduction to the Original Stories and Sayings of Jesus (Louisville, KY: Westminster John Knox, 2008), 1-40. On Q's significance for the study of Jesus see James M. Robinson, "The Critical Edition of Q and the Study of Jesus," in The Sayings Source Q and the Historical Jesus, ed. Andreas Lindemann, BETL 158 (Leuven: Peeters, 2001), 27-52.

2 On the Jewish-Christian context of Q see Robinson, "Critical Edition of Q," 47-48. See also Petri Luomanen, Recovering Jewish-Christian Sects and Gospels, SVigChr 110 (Leiden: Brill, 2012), 140-41. The common assumption among scholars is that Q was created in Galilee. Simon J. Joseph, Jesus, Q, and the Dead Sea Scrolls: A Judaic Approach to Q, WUNT II 333 (Tübingen: Mohr Siebeck, 2012), 74-87 and 187, has convincingly argued against this approach and the creation of a dichotomy between rural Galilee and Jerusalem/Judaea. He has shown that "Q contains polemic against Galilean villages" and that "the narrative world of Q begins and ends in Judea. Q is better understood as an ethnically and perhaps geographically Judean text" (ibid., 187). Giovanni B. Bazzana, Kingdom and Bureaucracy: The Political Theology of Village Scribes in the Sayings Gospel Q, BETL 274 (Leuven: Peeters, 2015), 54-81, perpetuates the "Galilean village scribe" model, which lacks a convincing socio-economic basis. There is no reason to assume that scribes who wrote in Greek would have been able to make a living in Galilean villages. On scribes, who are customarily associated with Jerusalem and the temple in Second Temple times, see also Catherine Hezser, Jewish Literacy in Roman Palestine, TSAJ 81 (Tübingen: Mohr Siebeck, 2001), 118-26. 
in Jesus' moral and theological instructions to his followers (Q 6:27-28: love your enemies; Q 10:2: send workers into the harvest). Only one text, the so-called "Lord's Prayer," provides more detailed instructions for prayer (Q 11:2b-4) and the belief in its efficacy (11:9-13). Q presents prayer as an integral part of Jesus' teaching that exemplifies his and his followers' relationship to God and to other human beings. ${ }^{3}$

Previous studies of prayer in Q have focused on the "Lord's Prayer" and the question whether and to what extent it was part of the Sayings Source. ${ }^{4}$ I shall look at all references to prayer in Q instead and discuss them in the context of early rabbinic literary sources and other sources on prayer in first- and secondcentury Judaism. If Q represents an early branch of Jewish-Christianity, a look at other Jewish sources may tell us more about the profile of this group. Two warnings are necessary at the outset, though. Firstly, the assumption that a somehow circumscribed local "community" stands behind a text seems problematic. ${ }^{5}$ The Sayings Source may be the product of one or a few Greek-speaking or bilingual compilers only, who were committed to transmit some (mostly oral and Aramaic?) Jesus-traditions that had come down to them in written (Greek) form. ${ }^{6}$ Secondly, the earliest rabbinic document, the Mishnah, was composed after 200 $\mathrm{CE}$ and the Tosefta and Tannaitic Midrashim may have been composed even later. These documents may contain traditions which, in some form or other, originated in earlier times, but there is no guarantee that their literary forms do not reflect later concerns and circumstances. ${ }^{7}$

3 According to Florian Wilk, “'So sollt ihr beten...': Das Vaterunser als Element der frühen Jesusüberlieferung," in Das Vaterunser in seinen antiken Kontexten: Zum Gedenken an Eduard Lohse, ed. Florian Wilk, FRLANT 266 (Göttingen: Vandenhoeck \& Ruprecht, 2016), 83-102, here $90, \mathrm{Q}$ preserves memories of various prayer practices of Jesus.

${ }^{4}$ See, e. g., John S. Kloppenborg, "Discursive Practices in the Sayings Gospel Q and the Quest of the Historical Jesus," in Lindemann, Sayings Source Q, 149-9o, here 178. See also Douglas E. Oakman, Jesus, Debt, and the Lord's Prayer: First-Century Debt and Jesus' Intentions (Eugene, OR: Cascade, 2014); Stephen C. Carlson, "Problems With the Non-Aversion Principle for Reconstructing Q," in Marcan Priority Without Q: Explorations in the Farrer Hypothesis, ed. John C. Poirier and Jeffrey Peterson, LNTS 455 (London: Bloomsbury T \& T Clark, 2015), 44-57.

${ }^{5}$ On the problematic term "community" see also Brian C. Dennert, John the Baptist and the Jewish Setting of Matthew, WUNT II 403 (Tübingen: Mohr Siebeck, 2015), 22.

6 There is a huge discussion on Q and orality, in regard to Q's sources and its own transmission; see, e. g., Delbert Burkett, Rethinking the Gospel Sources, vol. 2: The Unity or Plurality of Q, ECL 1 (Atlanta: Society of Biblical Literature, 2009), 46-47; Terence C. Mournet, Oral Tradition and Literary Dependency: Variability and Stability in the Synoptic Tradition and Q, WUNT II 195 (Tübingen: Mohr Siebeck, 2005), 43-45; and Jonathan A. Draper, "Jesus' 'Covenantal Discourse' on the Plain (Luke 6:12-7:17) as Oral Performance: Pointers to ' $Q$ ' as Multiple Oral Performance," in Oral Performance, Popular Tradition, and Hidden Transcript in Q, ed. Richard A. Horsley, SemeiaSt 60 (Atlanta: Society of Biblical Literature, 2006), 71-98, here 73-75, who argues that written transmission and oral tradition and performance could coexist. Most scholars believe that $\mathrm{Q}$ was composed in Greek, but it may be based on earlier Aramaic traditions; see, e. g., the discussion in Joseph, Jesus, Q, and the Dead Sea Scrolls, 51-62.

7 The latest sages mentioned by name in the Mishnah (e.g., R. Yehudah ha-Nasi, the as- 
In the following I shall argue that the prayer texts of the Sayings Source present Jesus in ways that are similar to the presentation of early Jewish charismatics in rabbinic sources. The descriptions of Jesus and other Jewish charismatics share the following motifs: prayer is presented as an always possible direct access to God that is believed to be effective and to receive an immediate response; the charismatic considers himself to be in an intimate relationship to God, compared to a child before his father. While some aspects, such as the monotheistic basis, are shared with rabbinic instructions on prayer, rabbinic texts differ from $Q$ especially as far as their interest in formalization and ritualization is concerned. The Jesus represented in the Sayings Source explicitly distances himself from "sages and the learned" (Q 10:21). This leads me to the assumption that Q tries to portray Jesus as an early Jewish charismatic who stood in a particularly close relationship to God and gave instructions to other Jews who might be willing to follow him and "work in the harvest" he had sown.

\section{A. Prayer as Individual Personal Expression Versus Prayer as Shared Jewish Ritual Practice}

Concerning prayer, the rabbis of the Mishnah were mainly interested in two aspects: in determining the "correct" prayer formulas and in discussing the proper times for prayers. Both concerns suggest an interest in standardization, although diversity in rabbinic opinions and historical uncertainty over rabbis' authority in liturgical matters suggest that prayers and the prayer service remained relatively unregulated until medieval times. ${ }^{8}$ In the first centuries $\mathrm{CE}$, the various local Jewish groups are likely to have followed their own customary practices, which the literary rabbinic opinions either reproduce or try to change and influence. The prayers that are repeatedly mentioned in rabbinic sources and that seem to have been the two most important prayers after $70 \mathrm{CE}$ are the Shema Yisrael and the Amidah or Tefillah ("the Prayer"), also called Eighteen Benedictions (Shemoneh Esreh), prayers that were time-bound and supposed to be recited by all Jewish men two (Shema) or three times (Amidah) daily. ${ }^{9}$

sumed editor of the Mishnah) date to approximately 200 CE Tannaitic midrashim were "mostly redacted at the beginning of the amoraic period (mid-third century)": see Avigdor Shinan, "Midrashic, Paytanic, and Targumic Literature," in The Cambridge History of Judaism, vol. 4: The Late Roman-Rabbinic Period, ed. Steven T. Katz (Cambridge: Cambridge University Press, 2006), 678-98, here 687 .

8 See Lawrence A. Hoffman, Beyond the Text: A Holistic Approach to Liturgy (Bloomington, IN: Indiana University Press, 1989), 28, who points out that "as late as the geonic period (ca. 7571038) disagreement continued, particularly in the Land of Israel, which continued to create new alternative texts and to insert them into the tefillah at different places."

${ }^{9}$ Note that Tannaitic documents do not provide the full text of the prayers; see also Reuven 
Whether and to what extent these prayers were already customary in Second Temple times is disputed among scholars. Stefan Reif has argued that an early form of the Shema, that is, Deuteronomy 6:4, was already "a daily prayer in the temple and outside it" and "one of the earliest forerunners of synagogal liturgy." 10 The other parts of the Shema may have been added only later: "Whether the whole passage (6:4-9) and the second paragraph (Deut 11:13-21) were also recited is a more controversial point." 11 Although some of the benedictions that make up the Amidah may have emerged before 70 already, discussions about the proper number, formulation, and order of the berakhot appear in Tannaitic texts only. ${ }^{12}$ A joined daily recitation of the Shema and Amidah also remains uncertain and, according to Reif, unlikely for temple times. ${ }^{13}$

One might argue that Jewish prayer was entirely unregulated in the first three quarters of the first century CE, both at the time of Jesus and when Q was created. Prayer may have been an individual and personal affair. Individuals may have formulated the texts themselves and recited them whenever they wished. Post-70 rabbinic attempts to regulate prayer and turn it into a more fixed religious ritual may have emerged as reactions to the vacuum left by the destruction of the temple and popular uncertainties as far as personal piety was concerned. Rabbinic insistence on a more formalized and regulated prayer practice may have been meant to unify Palestinian Jews in some shared rituals. ${ }^{14}$

Such a strict division between Jewish prayer before and after the destruction of the temple does not seem persuasive, however. Scholars no longer subscribe to the theory that so-called Yavnean rabbis fixed (the canon and) the liturgy. ${ }^{15}$

Kimelman, "The Shema and the Amidah: Rabbinic Prayer," in Prayer from Alexander to Constantine: A Critical Anthology, ed. Mark Kiley (London: Routledge, 1997), 108-20, here 108.

10 Stefan C. Reif, Judaism and Hebrew Prayer: New Perspectives on Jewish Liturgical History (Cambridge: Cambridge University Press, 1993), 83.

11 Ibid.

12 For discussions of past scholarship on the question whether the Amidah originated before or after $70 \mathrm{CE}$, see Richard J. Bautsch, Developments in Genre Between Post-Exilic Penitential Prayers and the Psalms, AcBib 7 (Atlanta: Society of Biblical Literature, 2003), 170; Jeremy Penner, Patterns of Daily Prayer in Second Temple Period Judaism, STDJ 104 (Leiden: Brill, 2012), 20.

13 Reif, Judaism and Hebrew Prayer, 84.

14 Various scholars of the past considered rabbinic attempts to regulate prayer a post-70 innovation: see the discussion in Penner, Patterns of Daily Prayer, 19-21, with reference to Solomon Zeitlin, "The Tefillah, the Shemone Esreh: An Historical Study of the First Canonization of the Hebrew Liturgy," JQR 54 (1964): 208-49; Ezra Fleischer, "On the Beginnings of Obligatory Jewish Prayer [Hebr.]," Tarbiz 59 (1990): 397-441; Lee I. Levine, "The Development of Synagogue Liturgy in Late Antiquity," in Galilee Through the Centuries: Confluence of Cultures, ed. Eric M. Meyers, Duke Judaic Studies 1 (Winona Lake, IN: Eisenbrauns, 1999), 123-44.

15 Against the old theory about a rabbinic "council" at Yavneh see, e. g., David E. Aune, "On the Origins of the 'Council of Javneh' Myth," JBL 110 (1991): 491-93. See also David M. Goodblatt, The Monarchic Principle: Studies in Jewish Self-Government in Antiquity, TSAJ 38 (Tübingen: Mohr Siebeck, 1994), 240. 
Rabbinic discussions on the proper formulations and times of prayers seem to have been an ongoing process that was based on pre-70 precedents and continued into the Middle Ages. As far as pre-70 precedents to prayer times are concerned, Josephus already mentions some customary practices among his fellow Jews. He states that Moses called for a twice-daily prayer (Ant. 4.212), a rule that lacks a scriptural basis. According to Steve Mason, Josephus sees the "Law ... through the filter of ... current practices familiar to him."16 Josephus may have known Jewish men of his time who prayed twice daily. Although this practice would have differed from the later rabbinic insistence on three daily prayer times (see m. Ber. 4:1), it indicates some Jews' adherence to a certain prayer pattern already in pre-rabbinic times. Penner has argued that in Second Temple times, "the custom of daily prayer was promoted as an important religious practice."17 "Fixed daily prayer" could have been legitimized in a number of ways, for example, by recurrence to Deut 6:7 ("when you lie down and when you rise up"), connecting prayer "to sleeping and rising within one's daily routine in the household." 18 Another possibility was to link the twice daily prayers to the morning and afternoon sacrifice in the temple. ${ }^{19}$ Although "prayer as a fixed daily practice was neither required nor encouraged formally by priests," some Jewish men may have adopted the practice. ${ }^{20}$

According to Mishnah Berakhot 4:1, "the morning Tefillah [can be recited] until midday, the afternoon Tefillah until evening, the evening Tefillah has no fixed [time]." The morning and afternoon recitation is probably modelled after the sacrificial services at the temple. Although the Shema is not mentioned here and the two prayers were originally separate, rabbis may have suggested a third evening recitation of the Tefillah to connect it with the recitation of the Shema that was scheduled to the mornings and evenings. ${ }^{21}$ Mishnah Berakhot 1:1-2 discusses the times for the recitation of the Shema:

[1:1] From what time onwards do they recite the Shema in the evening? From the time when the priests enter [their houses] to eat their heave offering [terumah] until the end of the first night watch, the words of R. Eliezer. And sages say: Until midnight. R. Gamaliel

16 Steve Mason, Flavius Josephus on the Pharisees: A Composition-Critical Study, StPB 39 (Leiden: Brill, 2001), 100.

17 Penner, Patterns of Daily Prayer, 209.

18 Ibid.

19 According to the gospels and Acts, prayer was linked to the temple and the time of the sacrifices, even if it took place at home: the temple is called a "house of prayer" (Mark 11:17, Matt 21:13, Luke 19:46). See also Luke 1:10 (people were standing outside the temple, praying, at the time of the incense sacrifice); Luke 18:10 (a Pharisee and a tax-collector went to the temple to pray); Acts 3:1 (Peter and John went to the temple in the ninth hour, at the time of prayer); cf. Acts 10:30 (Cornelius says that he prayed at the ninth hour in his house).

20 Penner, Patterns of Daily Prayer, 209.

${ }^{21}$ See also David Instone-Brewer, Traditions of the Rabbis from the Era of the New Testament, vol. 1: Prayer and Agriculture (Grand Rapids: Eerdmans, 2004), 53, commenting on this mishnah. 
says: Until the pillar of dawn arises .... [1:2] From what time onwards do they recite the Shema in the morning? From when one can distinguish between blue and white. R. Eliezer says: Between blue and green. And one concludes it by sunrise ....

Rabbis take the twice daily recitation of the Shema as a given here. Its twice daily recitation was probably already practiced by some Jewish men in pre-70 times. What rabbis are concerned with in this passage is to specify the exact time slots for the twice daily recitation. This Mishnah shows that, except for the broad categories of morning and evening, the more specific times to fulfill the biblical commandment remained disputed among sages throughout Tannaitic times.

The twice daily prayer mentioned by Josephus was probably some form of the Shema. There seems to have been a convention among some Jewish men to declare their commitment to Jewish monotheism (Deut 6:4: "Hear, O Israel, the Lord is our God, the Lord is one ...") when they got up in the mornings and when they went to sleep in the evenings. Whether an early form of the Amidah, or some of the blessings that eventually came to comprise it, was also recited by some Jewish men, perhaps already linked to the time of the (morning and) afternoon sacrifice at the temple, is also imaginable. Pieter van der Horst has recognized some elements that contributed to the Amidah in Philo's treatise In Flaccum (121-124). ${ }^{22}$ The text states that, after Flaccus's arrest, the Jews of Alexandria spontaneously prayed outdoors, since their proseuchai (houses of prayer, i. e. synagogues) had been desecrated. The prayer consists of hymns in praise of God. Jutta Leonhardt believes that "Flacc. 121-123 actually refers to the regular practice of prayer and perhaps even song in the proseuche." 23 As the name proseuche already indicates, prayer seems to have been one of the activities that took place in Egyptian (and probably also Palestinian) institutions by that name in Hellenistic and early Roman times. ${ }^{24}$

According to Mark 12:40, scribes “devour widows' houses and, for a pretence, make long prayers." ${ }^{25}$ It is uncertain whether the two allegations were associated with each other or should be understood separately. Are scribes accused of taking advantage of widows' houses, that is, using them for their own purposes, including prayer? This would be reminiscent of later rabbis' use of the "upper

22 Pieter W. van der Horst, "Common Prayer in Philo's In Flaccum 121-124," Kenishta 2 (2003): 21-28, reprinted in idem, Jews and Christians in Their Graeco-Roman Context, WUNT 196 (Tübingen: Mohr Siebeck, 2006), 108-13.

${ }^{23}$ Jutta Leonhardt, Jewish Worship in Philo of Alexandria, TSAJ 84 (Tübingen: Mohr Siebeck, 2001), 80.

${ }^{24}$ See also Josephus, Vita 290-295, where Josephus states that he prayed in the proseuche in Tiberias: "We were proceeding with the ordinary service and engaged in prayer ...." On this text see Daniel K. Falk, "Jewish Prayer Literature and the Jerusalem Church in Acts," in The Book of Acts in its First Century Setting, vol. 4: Palestinian Setting, ed. Richard Bauckham (Grand Rapids: Eerdmans, 1995), 261-301, here 278.

25 The text has a parallel in some textual witnesses of Matt 23:14. In Matthew, scribes and Pharisees are mentioned together. 
rooms" of wealthy hosts for Torah study. ${ }^{26}$ Or are the "long prayers" an additional charge that is added to the alleged exploitation of widows? Clearly the tradents and editors of the text viewed the "long prayers" negatively. The claim that the length of the prayers was not due to devotion but to pretence amplifies the negative image of the scribes created here. If the "long prayers" have any historical basis, one could imagine that particularly devout Jews recited long versions of the Shema, including both Deut 6:4-9 and 11:13-21, or that they expressed long praises of God that preceded the later Amidah.

To summarize this discussion, it seems that already in pre-70 times some Jewish men prayed twice - and perhaps sometimes also three times - daily. What seems to have characterized this prayer practice was not only the adherence to a certain chronological schedule informed by the Torah (Deut 6:7) and/or the sacrificial service of the Jerusalem temple, but also, at least in some cases, the public, congregational nature of prayer, and the adherence to certain shared, biblically informed formulas. I am not claiming that prayer practice became fixed and institutionalized in pre-destruction times already. But there seem to have been some - probably pious and learned - Jewish men who based their private and public prayer practices on the accepted traditional institutions of the Torah and the temple, conventions that later post-70 rabbis picked up and developed further.

The prayers associated with Jesus in the Sayings Source are entirely different. There is no concern about the number or the times of daily prayers. Nor is there an indication of any adherence to traditional biblical formulas such as the Shema or to the times of temple sacrifices. Instead, it seems that Jesus encourages his followers to pray whenever they need to (Q 11:9: "I tell you, ask and it will be given to you ...") and to use words that fit the occasion, expressing the particular concerns of the worshipers at a given time (Q 10:2: the need for Christian missionaries; Q 11:3: food, 11:4: cancellation of debts). Obviously, Q provides only scraps and pieces of the probably much larger tradition on Jesus and prayer that circulated in the first century CE. Nevertheless, the references point to an individual and personal prayer practice that does not follow traditional patterns. This type of personal and incidental prayer differs from the shared ritual practice advocated by rabbis that seems to have had precedents among some Jewish men before 70 already, as the above-mentioned references to Philo and Josephus suggest.

One might argue that the so-called "Lord's Prayer" (Q 11:2b-4) provided instructions for a new "communal" ritual among followers of Jesus, in the sense of a shared group practice among this set of Jewish Christians. Some scholars think that this portion did not belong to the Sayings Source or was added to it at a later

26 On rabbis' acceptance of non-rabbis' hospitality, e.g., in "upper rooms," see Catherine Hezser, The Social Structure of the Rabbinic Movement in Roman Palestine, TSAJ 66 (Tübingen: Mohr Siebeck, 1997), 355-56. 
stage. ${ }^{27}$ The synoptic versions of the prayer, especially in Matthew (6:9-13) but also in Luke (11:2-4), are much more elaborate and formal. Matthew explicitly presents the prayer as a private Christian alternative to existing Jewish prayer practices in synagogues and public places (cf. Matt 6:5-6). He introduces the prayer as an obligation that all followers of Jesus are supposed to follow (Matt 6:9). In $\mathrm{Q}$, on the other hand, followed by Luke (Luke 11:2), the prayer appears more like an occasional and voluntary practice: "When you pray, say: ...." The contents of the prayer, which will be discussed in more detail below, seem like a combination of a few traditional phrases (holy name, messianic kingdom) and the general needs of an impoverished (rural) population (daily bread, abolishment of debts). Whereas the Jesus of Q merely provides an example of how to formulate a short prayer when praying in private, Matthew has turned these suggestions into a formal (Jewish-?) Christian alternative to contemporary Jewish prayer practices.

Prayer is always a social act: "People are taught to pray, that is, they are socialized into prayer." 28 The Sayings Source seems to reflect an early stage of the process in which some Jewish Christians are taught to pray in a way that is partly based on but at the same time different from the prayer customs of other Jews. While traditional prayer patterns seem to be generally replaced by more personal and incidental addresses to God, the rudiments of the Lord's Prayer may reflect first steps toward early Jewish Christians' own more formalized prayer texts, later reflections of which can be found in Matthew and in the Didache. ${ }^{29}$

\section{B. The Prayer of a Jewish Charismatic: Jesus and Honi the Circle-Drawer}

Several aspects of the way in which Jesus' (instructions on) prayer are represented in the Sayings Source are reminiscent of the rabbinic presentation of Honi the circle-drawer's prayer in a story tradition transmitted in Mishnah Táanit 3:8.

27 See the discussion in Oakman, Jesus, Debt, and the Lord's Prayer, 50, with references.

28 W. S. F. Pickering, "Introduction to an Unfinished Work," in Marcel Mauss, On Prayer, ed. W. S. F. Pickering (New York: Durkheim/Berghahn, 2003), 12.

29 On the Lord's Prayer in Matthew and in the Didache, see Peter von der Osten-Sacken, "Das Vaterunser als Zugang zum Matthäusevangelium: Das Beispiel der Vergebungsbitte," in Wilk, Das Vaterunser in seinen antiken Kontexten, 103-24; Jürgen Wehnert, "Ein Gebet für alle christlichen Gemeinden: Zum Vaterunser in der Didache," in Wilk, Das Vaterunser in seinen antiken Kontexten, 143-62.

30 For general comparisons between Jesus and Honi, see e. g. the discussion of Geza Vermes's approach in Mark Allan Powell, Jesus As a Figure in History: How Modern Historians View the Man From Galilee (Louisville, KY: Westminster John Knox Press, 1998), 54-56; Ekkehard W. Stegemann and Wolfgang Stegemann, The Jesus Movement: A Social History of Its First Century (Edinburgh: T \& T Clark, 1999), 164; Alan J. Avery-Peck, "The Galilean Charismatic and Rabbinic Piety: The Holy Man in the Talmudic Literature," in The Historical Jesus in Context, 
The story is set in the Second Temple period. ${ }^{31}$ People are said to have asked Honi to pray for rain. When rain failed to materialize, "he drew a circle and stood within it, and said before him: 'Master of the Universe, your children turned to me, for I am like a child of the house [or: member of the household] before you [שאני כבן בית לפניך]. I swear by your great name that I shall not move from here until you have mercy on your children [בניך]'." His insistent prayer causes the rains to fall "as he ordered them." In reaction to Honi's behavior, Shimon b. Shetach criticizes him: "If you were not Honi, I would put you under a ban. But what can I do to you? For you are impertinent [מתחטא] before the Omnipresent and he grants you your wish [ועושה לך רצונך] like a child who is impertinent before his father and he grants him his wish. Scripture says of you: 'Your father and mother will rejoice; she who bore you will exult' [Prov 23:25]” (m. Ta'an. 3:8).

Rubenstein has already noticed that "the motif of parents and children runs throughout the story." 32 In his prayer Honi presents himself as a child in God's household. The validity of this self-presentation is confirmed by Shimon b. Shetach's eventual acknowledgment of his powers that are ascribed to his intimate relationship to God: he is like a naughty child before his father. The child-parent relationship reappears in the biblical proof text that is quoted at the end of the story. In Honi's direct address to God, those Jews who asked for his prayer for rain, that is, his local followers who believe in the efficacy of his intervention on their behalf, are also called "children" of God. The parent-child metaphor has precedents in biblical and especially prophetic texts. ${ }^{33}$ While it appears in three passages of the Mishnah, "in later Judaism mention is made ... rarely of God as Father of Israel. There seems to have been a tendency to avoid the designation." ${ }^{4}$

ed. Amy-Jill Levine, Dale C. Allison and John Dominic Crossan (Princeton, NJ: Princeton University Press, 2006), 149-65.

31 Josephus mentions a certain Onias, at the time of Hyrcanus and Aristobulus, whose prayer for rain was successful (Ant. 14.22): "Now there was one, whose name was Onias, a righteous man he was, and beloved of God, who, in a certain drought, had prayed to God to put an end to the intense heat, and whose prayers God had heard, and had sent them rain ...." Whether Onias was identical with Honi, or whether stories about several different rain makers circulated, remains uncertain.

32 Jeffrey L. Rubenstein, trans., Rabbinic Stories, CWS (New York: Paulist, 2002), 129.

${ }^{33}$ For a survey see Brent A. Strawn, "Israel, My Child': The Ethics of a Biblical Metaphor," in The Child in the Bible, ed. Marcia J. Bunge, Terence E. Fretheim, and Beverly Roberts Gaventa (Grand Rapids: Eerdmans, 2008), 103-40.

34 Martin McNamara, "Targum and the New Testament: A Revisit," in The New Testament and Rabbinic Literature, ed. Reimund Bieringer et al., JSJ.S 136 (Leiden: Brill, 2010), 387-427, here 405. The formula אב שבשמים appears five times in the Mishnah, three times in m. Soțah 9:15 ("our Father in heaven"), once in m. Yoma 8:9 ("your Father in heaven"), and once in m. Roš. Haš. 3:8 ("their Father in heaven"). McNamara wonders whether the terminology "was current in Palestinian Judaism at the time of Jesus, or whether its use in rabbinic Judaism is to be explained through influence from the Christian community" (ibid., 411). He assumes that early Christians used a Jewish expression that pre-dated Christianity. It should be noted that 
The terms "Lord" (אדוני), "Master" (רבונו של עולם), and "King" (מלכינו), which stress the distance between God and humans, are used instead.

Interestingly, a tradition in the Babylonian Talmud states that R. Aqiva implored "Our Father, our King" for rain and his prayer was effective:

Once R. Eliezer came before the Ark and recited the twenty-four blessings [said on fast days] but his prayer was not answered. R. Aqiva then came before the Ark and recited: "Our Father, Our King, we have no king but you. Our Father, Our King, have mercy upon us for your own sake!" whereupon the rain fell. (b. Taan. 25b)

The tradition, which lacks a Tannaitic parallel, seems to represent a late stage in the rabbinization of the charismatic tradition. Now a rabbi is presented as someone whose prayer causes rain to fall. The terminology, "Our Father, Our King," combines charismatic intimacy with the rabbinic insistence on God's sovereignty. ${ }^{35}$ As Reuven Hammer has pointed out, "the formula is a unique one, combining what are usually seen as two contradictory features, that of a parent who is loving and accepting, and that of a sovereign who is usually seen as stern and demanding." 36

Honi's emphasis on the intimate father-child relationship between the person who prays and the God he addresses is also evident in Jesus' prayer instructions in the Sayings Source. According to Q 10:21, Jesus said: "I thank you, Father, Lord of heaven and earth, for you hid these things from sages and the learned, and disclosed them to children. Yes, Father, for that is what it pleased you to do." Just as in the rabbinic story, where Shimon b. Shetach represents sages and Honi a popular charismatic, a distinction between Jesus, who identifies himself with "children" before God, and "sages and the learned" is drawn here. When viewed together with the rabbinic story in Mishnah Taanit 3:8, this Q text may preserve reminiscences of Jewish charismatics who distinguished themselves and their adherents from sages (scribes, Pharisees, rabbis) who claimed Torah knowledge and adherence to ancestral traditions for themselves. In contrast to these learned Jews, who emphasized the distance between humans and God and insisted that access to the divine is through intellectual knowledge and practice of his Torah only, the charismatics present a more simple, direct, and intimate way of communicating with God. For this intimate connection, the image of the child-parent relationship is used in both the Mishnah and the Sayings Source.

m. Sotah 9:15, where the appellation appears three times and which also deals with messianic times, is sometimes seen as a later addition to the Mishnah.

${ }^{35}$ This tradition is often seen as the origin of the Avinu Malkeinu prayer that "has been included in an expanded version in the services during the period from Rosh Hashanah through Yom Kippur with the exception of the Sabbath, when such penitential prayers are never recited .... It is recited standing, before the open Ark, following the repetition of the Amidah." So Reuven Hammer, Entering the High Holy Days: A Complete Guide to the History, Prayers, and Themes (Philadelphia: Jewish Publication Society, 2005), 67.

${ }^{36}$ Ibid., 68. 
Part of this analogy between $\mathrm{Q}$ and the Honi narrative is the presentation of prayer as efficacious, almost like a manipulation of God. In his prayer Honi threatens God to grant him his will: "I shall not move from here until you have mercy on your children." This behavior, which the sage Shimon b. Shetach calls "impertinent," is presented as effective in the story. It makes God react and rain fall, in accordance with Honi's (and the community's) wishes. Shimon acknowledges that Honi's relationship to God is so close that God allows him to act that way. References to the believed effectiveness of prayer also appear in the Sayings Source. In Q 11:9-10 Jesus tells his followers: "Ask and it will be given to you .... For everyone who asks receives." 37 In this same context the fatherson relationship is brought up again: "What person of you, whose son asks for bread, will give him a stone? Or again, when he asks for a fish, will give him a snake? So if you, though evil, know how to give good gifts to your children, by how much more will the Father from heaven give good things to those who ask him!" (Q 11:11-13). Like Honi, the Jesus of the Sayings Source evokes the intimate household relationship between his followers and God. Because of this great intimacy, their prayers will be effective and almost self-fulfilling: who asks will receive. Underlying this approach to prayer is the belief in God's loving care for his children: if they need rain, he will cause rain to fall; if they desire bread or fish, he will not leave them hungry. This simple and direct approach to the divine stood in contrast to the more reverential approach of sages, as both the Sayings Source and the Mishnah point out.

The mishnaic story is usually seen as a first step in the so-called rabbinization of charismatics who existed outside of rabbinic circles and posed a threat to rabbis' attempts to gain popular adherents. As a representative of sages, Shimon b. Shetach eventually concedes to Honi's religious power. At the same time, "the rabbinic storytellers appear to be uncomfortable with charismatic holy men who present an alternative and challenge to their authority." 38 The Sayings Source does not present "learned" Jews' reactions to the prayer instructions associated with Jesus. Yet the explicit distinction from "sages and the learned," from whom God is said to have "hidden things" (Q 10:21) ${ }^{39}$ may suggest that the tradents and

37 Craig A. Evans, Jesus and His Contemporaries: Comparative Studies, AGJU 25 (Leiden: Brill, 2001), 230, points to parables in Luke that take up the persistence motif: the parables of the Persistent Friend (Luke 11:5-8) and the Importunate Widow (Luke 18:1-8).

38 Rubenstein, Rabbinic Stories, 128. The rabbinization of Honi is carried further in the Babylonian Talmud: see b. Ta'an. 23a and Rubenstein, Rabbinic Stories, 130-35. On the analogous development of the Haninah b. Dosa tradition, see Baruch M. Bokser, "Wonder-Working and the Rabbinic Tradition: The Case of Haninah ben Dosa," JSJ 16 (1985): 42-92.

39 The so-called secrecy motif is usually seen as a feature of the gospel of Mark, relating to Jesus' messianic self-consciousness: see Ben Witherington, The Gospel of Mark: A Socio-Rhetorical Commentary (Grand Rapids: Eerdmans, 2001), 41; Heikki Räisänen, The Messianic Secret in Mark, SNTW (London: T \& T Clark, 1990). Q may represent an early, perhaps non-christological version of this motif. 
editors of $\mathrm{Q}$ were aware of other, more traditional forms of prayer among their Jewish contemporaries.

When distinguishing between the intimate and efficacious prayers associated with Jesus and Honi and the more formal and traditional prayer customs of "the learned," Max Weber's distinction between charismatic and tradition-based authority comes to mind. Although "charisma" remains a somewhat residual category in Weber's thought and too strict distinctions between the two types of authority fit neither ancient Judaism nor emerging Christianity, charisma as "extremely personal," "highly irrational," and "unusual" would suit the representation of Jesus in Q and Honi in the Mishnah, if looked at from a detached sociological point of view. ${ }^{40}$ Their intimate prayers to God as a father are "extremely personal," the belief in the prayers' efficacy is "highly irrational," and the religious practice they represent is more or less "unusual" in the Palestinian Jewish context in which they were active. A theological view of God as the "intimate immanent other" may lie at the roots of such prayer practices. ${ }^{41}$ The sages or "learned," on the other hand, may have held a more transcendent, reverential view of God. To some extent, these perceptions would have competed in ancient Jewish society, but they were never entirely antithetical, either. In Q, Jesus also instructs his followers to "bow down to the Lord, your God" (Q 4:8) and hopes for the coming of God's "reign" (Q 11:2b). The rabbis of the Mishnah could refer to God as their "Father in heaven" (e. g., m. Soțah 9:15).

\section{Shared Motifs in Q and in Rabbinic Texts}

In this final section I shall look at some motifs in Q that have analogies in rabbinic texts. Does the respective literary context suggest that they are used similarly or differently? The way in which motifs are combined, for example, in the "Lord's Prayer," is also relevant in this regard.

\section{Prostration Before God}

According to Q 4:5-8, the devil took Jesus on a high mountain and promised to give him "all the kingdoms of the world and their splendour," if he bowed down before him. Jesus refuses, since "it is written: Bow down to the Lord your God, and serve only him" (v. 8). In Roman society, prostration before emperors and idols was common and both may be alluded to here: the devil appears like a ruler

${ }^{40}$ For these characterizations of "charisma," see Christopher Adair-Toteff, Max Weber's Sociology of Religion (Tübingen: Mohr Siebeck, 2016), 31.

${ }^{41}$ Giuseppe Giordan, "Introduction: You Never Know. Prayer as Enchantment," in A Sociology of Prayer, ed. Giuseppe Giordan and Linda Woodhead (Farnham, UK: Ashgate, 2015), $1-8$, here 5 . 
showing Jesus his kingdom; yet he is also a false deity in comparison with the Jewish God. ${ }^{42}$ The story is also reminiscent of the Alexander legend: Alexander crossed high mountains, looked at the nations' wealth from above, and is criticized as greedy. ${ }^{43}$ Unlike Alexander, Jesus does not give in to temptations here but declares his loyalty to the one Jewish God. Addressing God as "Lord" fits the gesture of prostration that is carried out in front of a superior only.

As Uri Ehrlich has shown, "during the biblical period [full-body] prostration constituted the preeminent, most ritualized physical gesture in the sacrificial and prayer services. Mentioned over a hundred times in the context of serving God, the biblical verb השתחחויה came to denote divine worship in general." 44 Rabbis, on the other hand, reserved the more moderate form of bowing [שחייה] one's head or upper torso to certain benedictions of the Amidah. ${ }^{45}$ Tosefta Berakhot 1:8 rules: "These are the benedictions during [the recitation of] which one bows: the first benediction [of the Amidah], at the beginning and the end, [and the penultimate benediction], 'We give thanks,' at the beginning and the end. One who bows through each and every benediction, they instruct him not to bow." Ehrlich stresses that "this is the sole halakhah relating to this subject found in Tannaitic literature." 46 Obviously, rabbis were not very fond of the gesture and tried to restrict it as much as possible. This was probably due to its association with pagan worship. ${ }^{47}$ The formula, "the Lord your God," in front of whom Jesus suggests to bow down in the Sayings Source, is reminiscent of אדוני אלהינו in the Shema (Deut 6:4: "Hear, O Israel, the Lord is your God ..."), but the recitation of the Shema does not require bowing. In any case, a prayer is not explicitly mentioned in Q 4:8, where the emphasis is on Jewish monotheism (“serve only him").

42 C. E. V. Nixon and B. Saylor Rodgers, In Praise of Later Roman Emperors: The Panegyrici Latini: Introduction, Translation, and Historical Commentary, Transformation of the Classical Heritage 21 (Berkeley, CA: University of California Press, 1994), 52: "At Rome both gods and men were recipients of this form of supplication."

43 See, e. g., Richard Stoneman, ed., The Greek Alexander Romance (London: Penguin, 1991), 147: "We left there and came to the harbor of Lyssos. Here there was a very high mountain which I climbed and saw beautiful houses full of gold and silver. I also saw a perimeter wall of sapphire ...." Rabbis were critical of Alexander's hubris: see y. B. Mes. 2:5, 8c, where he is presented as greedy.

44 Uri Ehrlich, The Non-Verbal Language of Prayer: A New Approach of Jewish Liturgy (Tübingen: Mohr Siebeck, 2004), 38.

45 See ibid., 42.

46 Ibid., 31.

47 The governor of Africa allegedly asked a Christian woman on trial to "bow your head to the sacred rites of the Roman gods .... However devoted you are, we ask that you bow your head in the sacred temples and offer incense to the gods of the Romans" (Acts of Crispina 1.3-4, 2.1, 2.4), quoted in Mary Beard et al., Religions of Rome, vol. 1: A History (Cambridge: Cambridge University Press, 1998), 242. Although the text relates to late antiquity, there would have been a long tradition of bowing and prostration in Roman religion. 


\section{Praying for One's Persecutors}

In Q 6:27-28 Jesus instructs his followers: "Love your enemies and pray for those persecuting you, so that you may become sons of your Father, for he raises his sun on bad and good and rains on the just and unjust." The notion not to delight in one's enemies' misfortune already appears in the Hebrew Bible, as John Piper has shown. ${ }^{48}$ Especially noteworthy is Psalm 24:17: "Do not rejoice when your enemy falls and let not your heart be glad when he stumbles." The positive commands to "love" one's enemies and to pray for one's persecutors obviously goes a step further, though. In its connection with prayer, the Q text is reminiscent of Philo in In Flaccum. When the Roman governor Flaccus, who had persecuted Jews and brought various calamities over them, a situation which Pieter van der Horst calls "the first pogrom," 49 was arrested, Alexandrian Jews are said to have raised their hands to heaven and sung a hymn in praise to God: "O Lord, we are not delighted at the punishment of our enemy, for we have learned from our holy laws that we should sympathize with our fellow men. But it is right to give thanks to you for having taken pity and compassion on us and for having relieved our constant and incessant oppression" (Flacc. 121). ${ }^{50}$ The prayer almost sounds like an excuse for praising God for his protection. In the spirit of the mentioned biblical idea to "sympathize" with all human beings, even those who may persecute oneself, the Jews express their thanks to God for having saved them from the governor's harsh rule.

The Sayings Source goes on to present a reason for the instruction to love one's enemies and to pray for one's persecutors, referring to God himself as a model to emulate: "he raises his sun on bad and good and rains on the just and unjust" (Q 6:35c-d), that is, God's providence extends to all of humanity. He provides everyone with their basic needs. An analogy to this notion appears at the end of the Alexander story transmitted in the Talmud Yerushalmi and Amoraic Midrashim. ${ }^{51}$ According to all versions of the story, Alexander of Macedon went to the king of Qasya (y. B. Meș. 2:5, 8c; Gen. Rab. 33:1; Lev. Rab. 27:1). The midrashic versions add "beyond the mountains of darkness." 52 The king "showed him a lot of gold and a lot of silver." Although Alexander maintains that he is not

48 John Piper, "Love Your Enemies": Jesus' Love Command in the Synoptic Gospels and in Early Christian Paraenesis, SNTSMS 38 (Cambridge: Cambridge University Press, 1979), 28-35, with references.

49 Pieter W. van der Horst, Philo's Flaccus: The First Pogrom. Introduction, Translation, and Commentary, PACS 2 (Leiden: Brill, 2003). On the historical background of the treatise see ibid., 18-34; on Flaccus see ibid., 34-37.

50 Translation with van der Horst, Jews and Christians, 108.

51 On this story see Catherine Hezser, Form, Function, and Historical Significance of the Rabbinic Story in Yerushalmi Neziqin, TSAJ 37 (Tübingen: Mohr Siebeck, 1993), 61-77.

52 As already mentioned above, there is a certain analogy to Q 4:5-8, where the devil shows Jesus his kingdom from the top of a mountain, testing his greediness. Unlike Jesus, Alexander turns out to be a greedy and wicked person, not deserving God's mercy. 
greedy, he turns out to be just that: "he loved gold and silver so much" (y. B. Meș. $2: 5,8 \mathrm{c}$ ). At the end of the story, in reaction to Alexander's behavior,

the king [of Qasya] said to him: Does the sun shine upon you? He said to him: Yes. Does the rain come down upon you? He said to him: Yes. He said to him: Perhaps there is small cattle with you [i. e., where you live]? He said to him: Yes. [He said to him:] May that man's breath expire! ${ }^{53}$ You live only through the merit of the small cattle, as it is written: 'Man and cattle do you save, God' [Ps. 36:7]. (y. B. Meș. 2:5, 8c)

Alexander is presented as so wicked here that God's providence, which was believed to cover both humans and animals, exempts him. ${ }^{54}$ If he and his countrymen nevertheless enjoy sunshine and rain, which are necessary for agriculture to prosper, this must be due to God's concern for the well-being of the small cattle, whose merits preserve their human owners.

The notion that God protects all human beings, irrespective of their deeds, underlies both the Alexander story and the Q text. This notion seems to reflect ancient people's experience, for everyone is equally affected by the sun and rain. The comparison between the Saying Source and the rabbinic text shows that $\mathrm{Q}$ is more neutral in its views concerning "bad" and "unjust" people. In line with the suggestion to pray for one's persecutors, the model of God extending his sun and rain over all people, irrespective of their behavior, remains unqualified. The rabbis who formulated the Alexander story, on the other hand, use Psalm 36:7 to reinterpret the idea of a universal divine providence: the wicked are not worthy of it; it is the lowest of the low animals through whose merit they live.

\section{The Workers in the Harvest Parable}

In Q 10:2 Jesus tells his disciples "The harvest is plentiful, but the workers are few. So ask the Lord of the harvest to dispatch workers into his harvest." ${ }^{2}$ Firstcentury Jews would have been very familiar with the need for additional agricultural workers during harvest seasons, when crops had to be gathered in. The Mishnah deals with legal issues that might emerge in such a situation. For example, m. Ma'as. 2:7 rules: "If a man hired a worker to help him harvest figs," he may eat the figs and is exempt from tithe. The metaphorical use of the worker as

53 The Escorial manuscript of the Talmud Yerushalmi adds here: "Through the merit of the small cattle does the sun shine upon you, and dew and rain come down only through the merit of the small cattle."

54 For other critical presentations of Alexander that counter the idealized image of the Alexander Legend and present him as a pirate and brigand who looted the regions he conquered, see, e.g., Curtius Rufus, Hist. Alex. Magn. 9.8.12-30 and Augustine, Civ. 4.4, quoted in M. M. Austin, The Hellenistic World From Alexander to the Roman Conquest: A Selection of Ancient Sources in Translation, 2nd ed. (Cambridge: Cambridge University Press, 2006), 59. See also 1 Macc 1:1-9: "He marched to the end of the earth, and seized plunder from a mass of peoples ..." (quoted ibid., 6o).

55 See Matt 9:37-38 par. Luke 10:2. 
an image of human beings before God appears several times in Mishnah Avot. ${ }^{56}$ In analogy to the $\mathrm{Q}$ saying, a statement attributed to $\mathrm{R}$. Tarfon is particularly relevant: "The day is short, the work is large, the workers are lazy, and the salary is much, and the householder urges [to get the work done]" (m. 'Abot 2:15). The Mishnah continues: "It is not up to you to finish the work, but you are also not free to stay away from it" (2:16). As in the Sayings Source, the image of a large amount of work is evoked here. Similarly, there is an urgency to get the work done. Whereas Q refers to a lack of workers, Mishnah Avot mentions their laziness. These different details may indicate the different meanings of the parables in the different contexts. Whereas R. Tarfon's saying tries to motivate Jews to be more efficient in their Torah observance (the "work"), Jesus' saying seems to encourage more Jews to become missionaries on behalf of Jewish Christianity (the "harvest"). 57

\section{The Cancellation of Debts}

In the so-called "Lord's Prayer" one of the requests is the cancellation of debts: "and cancel our debts for us, as we too have cancelled for those in debt to us" (Q 11:4). The image of debts would have had a strong impact on first-century Jews. Josephus associates the attempt to eliminate impoverished people's debts with Zealot leaders, as a means to gain adherents at the beginning of the First Revolt against Rome. In 66 CE the Sicarii allegedly burned down the public archives in Jerusalem, where the debt documents were kept. They were "eager to destroy the money-lenders' bonds and to prevent the recovery of debts, in order to win over a host of grateful debtors, and to cause a rising of the poor against the rich, sure of impunity" (B. J. 2.427).$^{58}$ Oakman views the request for the cancellation of debts in the "Lord's Prayer" against the social background of wide-spread debts among first-century Jews. He argues that the prayer "shows direct interest in the alleviation or mitigation of agrarian money debts." 59 Anyone who read or heard the formulation in Q must have considered Jesus an advocate for the release of debts, in analogy to the Zealot leaders described by Josephus.

56 Some scholars consider m. 'Abot to be a creation of the third to fourth century. Amram Tropper, "Tractate Avot and Early Christian Succession Lists," in The Ways that Never Parted: Jews and Christians in Late Antiquity and the Early Middle Ages, ed. Adam H. Becker and Annette Yoshiko Reed, TSAJ 95 (Tübingen: Mohr Siebeck, 2003), 159-88, here 160, argues however that "the traditionalists were correct to regard Avot as a Mishnaic tractate" (see ibid., 160 n. 3 for a detailed discussion of the various opinions).

57 Frederick Dale Bruner, Matthew: A Commentary, vol. 1: The Christbook, Matthew 1-12 (Grand Rapids: Eerdmans, 2004), 450, interprets Matt 9:37-38 as a reference to the Christian mission.

58 Translated with S. G. F. Brandon, Jesus and the Zealots: A Study of the Political Factor in Primitive Christianity (Manchester: Manchester University Press, 1967), 56.

59 Oakman, Jesus, Debt, and the Lord's Prayer, xi. 
The mutuality of the debt release envisioned in the Sayings Source may indicate that its meaning is theological and moral. Those whose debts are released by God are required to also release the debts of their fellow-human beings. Yet the debts of fellow-human beings may also be real material debts that the Jewish Christians who formulated the text confirm to have cancelled for their debtors (note that the formulation is in the past tense). If understood in this way, the release of debts by God, that is, the cancellation of sins (cf. Luke 11:4, who has replaced "debts" with "sins"), ${ }^{60}$ may almost be considered a reward for the worldly moral action: we acted morally ourselves, so treat us leniently when it comes to our own failings. What is interesting here and reflective of biblical and rabbinic thinking is the importance of ethics, that is, the way one treats other human beings, in one's relationship with God. The way one acts towards others is closely related to the treatment one can expect of God. Humans are considered "capable of making moral choices and taking responsibility for those choices." ${ }^{1} 1$ Therefore "the social legislation in the Bible, particularly laws concerning the care of the poor, the widow, the orphan, and the stranger, occupies a position of paramount importance." 62

\section{Prayer for Food and the Grace After Meals}

The provision of food, especially bread as the basic staple of the ancient diet, seems to have been an important concern of the editors of the Sayings Source. ${ }^{63}$ Bread is mentioned in the "Lord's Prayer" (Q 11:3) as well as in the following passage about the efficacy of prayer ( $Q$ 11:11), a text that also refers to fish as an important food (Q 11:12). Fish was probably part of Sabbath meals, especially among those who lived close to the Sea of Galilee. ${ }^{64} \mathrm{Ze}$ 'ev Safrai assumes that it "was consumed in great amounts," but that probably depended on its avail-

60 Nicholas Ayo, The Lord's Prayer: A Survey Theological and Literary (Notre Dame: University of Notre Dame Press, 1991), 72, points to the differences between Matthew and Luke: "Matthew writes of forgiving debts, and Luke of forgiving sins ... Matthew's 'debts' shows a more Semitic usage. The Aramaic word for sins was debts, with the primary analogue financial debts. To the Greek Gentile Christians of Luke's community, however, sins would be more understandable."

61 Samuel Tobias Lachs, Humanism in Talmud and Midrash (Rutherford, NJ: Fairleigh Dickinson University Press, 1993), 37.

62 Ibid., 57.

63 On the centrality of bread in the ancient diet see Andrew Dalby, Food in the Ancient World From A to $Z$ (London: Routledge, 2003), 59. Nathan MacDonald, What Did the Ancient Israelites Eat? Diet in Biblical Times (Grand Rapids: Eerdmans, 2008), 19, points to the triad of "bread, wine, and oil" as the basic food stuffs: "For the typical Israelite, bread or other grainbased foods such as porridge probably provided over half their caloric intake, with estimates varying between 53 and 75 percent."

64 According to t. Pe'ah 4:8, the Sabbath foods of a poor person consisted of "oil, legumes, fish, and a vegetable." On fish as a Sabbath food see also Jordan D. Rosenblum, Food and Identity in Early Rabbinic Judaism (Cambridge: Cambridge University Press, 2010), 174. 
ability. ${ }^{65}$ In Q food is presented as a "gift" given to humans by God. The request for bread in the "Lord's Prayer" (Q 11:3) is followed by the firm belief that God will provide his "children" with bread and fish (Q 11:11-12). As such, the prayer is reminiscent of another text in Q that tries to alleviate anxiety about daily provisions: "Therefore I tell you, do not be anxious about your life, what you are to eat .... Consider the ravens: they neither sow nor reap nor gather into barns, and yet God feeds them" (Q 12:22b, 24).

The notion that it is ultimately God who provides food to humans also underlies the rabbinic blessing before eating food and the Grace After Meals. These blessings express thanks to God for the foods that form part of the meal. Mishnah Berakhot 6:1 lists the blessings that one is supposed to say over the different types of products: "over bread one says: [Blessed Are You, O Lord Our God, King of the Universe], who brings forth bread from the earth." The blessing holds God responsible for the agricultural harvest. Over food that does not come out of the earth one says the blessing, "For all came into being by his word" (m. Ber. 6:3). Although rabbis required the recitation of such a blessing before meals, the so-called Grace After Meals was considered more important, since it was based on a biblical commandment. According to Deut 8:10, "When you have eaten your fill, give thanks to the Lord your God for the good land which he has given you." Since the land is mentioned here, rabbis required the Grace After Meals for products that emerged from the earth only, the so-called seven kinds of produce, which were given precedence over other foods (cf. m. Ber. 6:4-5). Unlike the short blessing before meals, the Grace After Meals was "a full-blown liturgy consisting of four blessings." 66 Joseph Tabory summarizes as follows: "The motif of the first blessing is praise of God who sustains the world; the second, thanks God for the gift of the land of Israel; the third, a prayer for the rebuilding of Jerusalem; and the fourth is a general praise of God 'who is good and does good." 67 The Grace After Meals thanks God in much more general terms, then, rather than focusing on specific foods.

Based on the shared assumption that it is God who ultimately provides food, the difference between the $\mathrm{Q}$ prayer and the mishnaic instructions becomes obvious. The Q prayer is a plea to God that lists various requests, the "daily bread" being one of them. The rabbinic prayers, on the other hand, are prayers of thanks for the food that God has provided and continues to provide daily. The different formulations point to different occasions. The rabbinic blessing of food and Grace After Meals are recited before and after an actual meal. Jesus' prayer in Q,

65 Ze'ev Safrai, The Economy of Roman Palestine (London: Routledge, 2003), 92.

66 Joseph Tabory, "Prayers and Berakhot," in The Literature of the Sages, part 2: Midrash and Targum, Liturgy, Poetry, Mysticism, Contracts, Inscriptions, Ancient Science and the Languages of Rabbinic Literature, ed. Shmuel Safrai et al., CRINT 2.3a (Assen: Royal Van Gorcum; Minneapolis: Fortress, 2006), 281-326, here 321.

67 Ibid. 
on the other hand, is a more general prayer that is not linked to a specific occasion. ${ }^{68}$ It expresses the concerns of those who formulated it, concerns that are both pragmatic (bread; release of debts) and religious (hope for the beginning of the messianic kingdom; the forgiveness of sins; fear of being tested by the devil).

One might argue that the request for "daily bread" would have been most likely for someone who did not work in agriculture and food production (i. e., someone who did not live in rural Galilee and/or was itinerant?) and worried about where his or her daily provisions would come from. Prayer obtains an important role in Q. It serves to implore God to provide for his “children.” As already mentioned above, this direct approach and the belief in the efficacy of prayer are reminiscent of Honi's prayer for rain, which can likewise be called an appeal or imploration, something rabbis, represented by Shimon b. Shetach, considered importunate. These requests, which were guided by the belief in their efficacy, were not supplications. ${ }^{69}$ Rather than humbly approaching God to ask for his mercy, they formulate demands that God was supposed to fulfill, if he wanted to maintain the image of a loving father. The person formulating the prayer puts himself in the role of a naughty child who believes that his parents will fulfill his wishes, no matter what he does and how he behaves. Ulrich Luz has called this type of prayer a "conflict talk with God," "a dialogical wrestling with God" that views God as "a living dialogue-partner." ${ }^{70}$ As such, it is more reminiscent of the biblical book of Job than of rabbinic prayer discourse.

\section{Conclusions}

The different ways in which prayer is represented in the Sayings Source and in early rabbinic texts point to different forms of Jewish religiosity and views of God in first and second century CE Palestinian Judaism. The Sayings Source presents Jesus and his followers in a close child-father relationship with God. The use of

68 On the formal difference between prayers of request, "asking for something that you don't have at that moment," and prayers of thanksgiving see Carlo Genova, "Prayer as Practice: An Interpretative Proposal," in Giordan and Woodhead, A Sociology of Prayer, 9-23, here 13.

69 Rabbis also knew of supplications (תחנונים) and welcomed them; see m. Ber. 4:4. They consisted of private petitions that are formulated in silence rather than being said aloud. They were probably formulated after the public recitation of the Amidah in rabbinic times. See Ismar Elbogen, Der jüdische Gottesdienst in seiner geschichtlichen Entwicklung, 3rd ed. (Frankfurt: J. Kauffmann, 1931), 73-75. Elbogen sees the origins of these supplicatory prayers in temple times and refers to Sir 50:16-21: when the priests sounded the silver trumpets, "all the people together ... fell down to the earth upon their faces to worship their Lord God Almighty .... And the people besought the Lord, the Most High, by prayer before him that is merciful ..." (vv. 17-19).

70 Ulrich Luz, "Why Do Theologians Speak about God When They Speak about Humans?, in Theologies of Creation in Early Judaism and Ancient Christianity: In Honour of Hans Klein, ed. Tobias Nicklas and Korinna Zamfir, DCLS 6 (Berlin: de Gruyter, 2010), 1-16, here 11. 
the parenthood metaphor suggests that God is regarded as a loving and forgiving father who tolerates his child's impertinent behavior and indulges him or her with gifts. This view also determines the prayer language: toward a father one can be direct, clear, and demanding, relinquishing any courtesies. The simple and direct prayer was believed to be more effective than any long-winded and carefully formulated prayer of the "learned" could ever be. This approach to the divine is reminiscent of Honi the circle-drawer in a Tannaitic story. By behaving like an insistent child, he could "force" God to make rain fall.

Rabbis underline the difference between Honi's approach and their own, which assumed a more distant, courteous attitude and behavior toward God. For rabbis, God was the Lord, king and master, whose instructions one had to carefully study and obey. They believed that daily prayer habits were part of these instructions that had to be followed and adapted to post-temple times. Accordingly, they discussed the proper times of prayers such as the Shema and Amidah and the Amidah's formulation. It is likely that this discourse continued discussions and practices that already emerged among some Jews in Second Temple times. For rabbis, just as for Philo and Josephus, prayer had traditional roots in the Hebrew Bible (the text of the Shema, formulations of the Amidah) and was linked to the temple and its sacrificial times. Although prayer formulas continued to be diverse throughout rabbinic times, rabbis viewed prayer as a shared ritual that all Jewish men should practice in approximately the same way.

Despite these differences, a certain overlap between prayer in $\mathrm{Q}$ and rabbinic prayer can be recognized. Both the Jesus of Q and rabbis were committed to biblical monotheism. They emphasized the importance of moral behavior in one's relationship with God. They knew that God's providence extended over all humans. While the tradents and editors of the Sayings Source were also familiar with God as the Lord, rabbis would occasionally use the Father metaphor.

The mentioned differences together with the shared concepts suggest that we are dealing here with variant forms of ancient Jewish religiosity that could coexist and be practiced by some of the same people. Just as Honi's closeness to God was appreciated by rabbis and eventually integrated into their own self-presentation, some pre-70 Pharisees and scribes may have been attracted to "charismatic" individuals and their more direct approach to God. Max Weber's categorical distinction between "charismatic" and "traditional" authority therefore seems to be too rigid. Ultimately, the representations of Jesus' prayer in Q and of Honi's and early rabbis' prayers in Tannaitic sources constitute religious varieties within Palestinian Judaism of the first centuries CE. Whether the so-called "Lord's Prayer" is indicative of the constitution of a specific Jewish Christian "community" of Jesus followers is possible but uncertain, since the Q version of the prayer remains rudimentary. 